\title{
PELATIHAN BUDIDAYA METODE VERTICAL GARDEN DALAM MENGHADAPI MASA PANDEMI COVID 19
}

\author{
Muhammad Rizqi Zati' ${ }^{1}$, Murdhiani²), Dhian Rosalina ${ }^{1)}$ \\ ${ }^{1)}$ Program Studi Manajemen, FE, Universitas Samudra, Kota Langsa, Aceh, Indonesia \\ 2)Program Studi Agroteknologi, FP, Universitas Samudra, Kota Langsa, Aceh, Indonesia \\ Corresponding author : Dhian Rosalina \\ Email : dhian.rosalina@unsam.ac.id
}

Diterima 25 September 2020, Direvisi 14 Oktober 2020, Disetujui 15 Oktober 2020

\begin{abstract}
ABSTRAK
Kegiatan Pengabdian ini merupakan pelatihan menggunakan metode vertical garden dengan paralon sebagai media tanam Tujuan kegiatan adalah membina dan memberdayakan mitra dengan memotivasi bahwa pemanfaatan pekarangan rumah untuk bercocok tanam merupakan modal serta peluang dalam meningkatkan ekonomi keluarga. Metode budidaya vertical garden pada dasarnya adalah metode bercocok tanam dengan rangkaian tanaman yang ditanam di atas media tanam kemudian disusun secara vertikal, dan dapat digunakan secara mandiri di pekarangan serta dimanfaatkan menjadi apotik dan warung hidup, taman pekarangan akan membantu keluarga mengatasi turunnya daya beli sebagai akibat pandemik covid 19. Pengabdian dilaksanakan di gampong baroh Langsa Lama yang terletak di kecamatan Langsa Lama, kota Langsa, Aceh, metode yang digunakan dalam kegiatan ini adalah sosialisasi, pelatihan, dan pendampingan terhadap mitra. Dengan mitra pengabdian adalah 30 orang masyarakat buruh harian lepas di desa Baroh Langsa Lama, yang tidak memiliki penghasilan tetap, maka diharapkan kegiatan ini tepat sasaran meningkatkan ketahanan pangan mitra. Kesimpulan kegiatan ini adalah 1) Kegiatan ini membantu mitra memanfaatkan media tanam paralon untuk menanam sayur sayuran yang diperlukan keluarga, 2) Hasil dari kegiatan ini adalah mitra mampu membuat sendiri media tanam dari paralon, kemudian mitra dapat melakukan pembibitan sampai dengan panen hasil tanam.
\end{abstract}

Kata kunci : budidaya metode vertical garden; ketahanan pangan.

\begin{abstract}
This activity is a training and empowerment using the vertical garden method with a paralon as a planting medium. The purpose of the activity is to empower partners with the motivation that the use of house yards for farming is an asset and an opportunity to improve the family economy. The Vertical Garden method is a farming technique with a series of plants planted on the planting medium and then arranged vertically, and can be used in the yard or in the house. Thus, it can help families overcome the impact of the recession as a result of the Covid 19 pandemik. This activity was carried out in the Baroh Langsa Lama village which is located in the Langsa Lama district. The methods used in this activity are outreach, training, and mentoring to partners. With daily laborers as activity partners, who live in the village of Baroh Langsa Lama, who do not have regular income, it is hoped that this activity will be right on target in increasing the partner's food security. The conclusions of this activity are as follows: 1 ) This activity helps partners utilize planting media such as paralon and so on to grow vegetables needed by the family, 2) The result of this activity is that partners are able to make their own planting media from Paralon, then partners can carry out seeds until the harvest of the planting results
\end{abstract}

Keywords: cultivation of the vertical garden method; food security.

\section{PENDAHULUAN}

Ketika wabah pandemik covid 19 masuk ke Indonesia pada awal Maret 2019. Pemerintah segera merespon dengan menerapkan pembatasan dengan kebijakan social distancing (jaga jarak sosial, menghindari kerumunan), lalu physical distancing (jaga jarak antar orang minimal 1,8 meter) (Hadiwardoyo, 2020; Masniadi, Angkasa, Karmeli, \& Esabella, 2020)
Kebijakan itu berdampak besar dalam menurunkan secara drastis aktivitas dan pergerakan orang di Jabodetabek dan wilayah lain di Indonesia, termasuk Kota Langsa. Secara ekonomi, pandemi covid 19 menurunkan daya beli masyarakat secara umum, dikarenakan pembatasan untuk pencegahan wabah, sehingga kegiatan usaha terbatas dan menimbulkan dampak penurunan daya beli 
masyarakat karena adanya PHK, kemampuan pengusaha dalam memberikan gaji, dan lain sebagainya (Hanoatubu, 2020)

Kebutuhan akan pangan yang berkualitas merupakan faktor yang sangat penting dalam menciptakan sumber daya manusia yang sehat (Masniadi et al., 2020; Putri, Syafril, Hutama, Nugraha, \& Semarang, 2020) Ketahanan pangan adalah aspek penting dalam memenuhi gizi seimbang untuk menghadapi wabah pandemik yang saat ini sedang berlangsung di Indonesia bahkan seluruh dunia (Karim, 2020; Saragih \& Mulawarman, 2020) Salah satu cara untuk mengatasi permasalahan ini adalah keaktifan masyarakat secara mandiri dalam memanfaatkan pekarangan dan ruang di hunian masing masing sebagai tempat untuk menanam sayur dan buah buahan (yudha et al.,2020) . Keaktifan masyarakat secara mandiri membangun ketahanan pangan di tingkat rumah tangga akan dapat membantu mengatasi permasalahan ketersediaan pangan yang bergizi dalam menghadapi pandemik, sekaligus sebagai upaya mensiasati turunnya daya beli masyarakat pada umumnya.

Selanjutnya melihat kenyataan dewasa ini, harga sayur maupun harga buah-buhan semakin tinggi, maka bercocok tanam secara mandiri di pekarangan maupun hunian dapat dimanfaatkan menjadi apotik hidup, warung hidup, taman pekarangan akan membantu keluarga dalam mengatasi turunnya daya beli sebagai akibat pandemik covid 19.

Metode vertical garden pada dasarnya adalah metode dimana rangkaian tanaman yang ditanam di atas media tanam kemudian disusun secara vertical. Atau dengan kata lain, bercocok tanam pada bidang yang posisinya tegak lurus dengan tanah (Damayanti Asikin, Rinawati, 2016). Teknik penanaman vertical garden hampir menyerupai hidroponik, dengan media yang digunakan antara lain: seperti bambu, kayu, pipa paralon, pot gantung dan tidak menggunakan tanah sebagai media tanam. Keuntungan dari teknik ini adalah : 1) Perawatan tumbuhan lebih praktis, karena tidak membutuhkan tanah melainkan sedikit saja, 2) Lebih aman dari hama dan penyakit yang berasal dari dalam tanah, 3) Efektif dalam memanfaatkan lahan yang dimiliki, 4) Dapat menghasilkan sayur sayuran yang bergizi untuk memenuhi kebutuhan sehari hari seperti : seperti bayam, kangkung, sawi, tomat, cabai, brokoli, gambas, pare, daun bawang, dan labu, 5) Dari segi estetika dapat mempercantik hunian.

Pelatihan dan pendampingan budidaya metode vertical garden dalam menghadapi masa pandemik covid19 dilakukan di gampong baroh Langsa Lama yang terletak di kecamatan
Langsa Lama. Dengan mitra pengabdian adalah masyarakat buruh harian lepas di desa/gampong Baroh Langsa Lama, berdasarkan data yang dilansir dari BPS Kota Langsa, di kecamatan Lama terdapat 859 penduduk yang berstatus pra sejahtera yang pada umumnya tidak memiliki pekerjaan dan penghasilan tetap setiap bulannya. Dengan demikian sasaran kegiatan pengabdian diharapkan tepat sasaran dan mampu memotivasi mitra untuk meningkatkan pendapatan, sekaligus menjaga kesehatan keluarga.

\section{Permasalahan Mitra}

Permasalahan yang dihadapi oleh mitra adalah sebagai berikut :

1. Rendahnya kesadaran masyarakat, khususnya mitra yang merupakan buruh harian lepas di desa/gampong Baroh Langsa Lama dalam menghadapi pandemik covid 19, terutama dalam hal pemenuhan asupan gizi dan peluang ekonomi. Hal ini terlihat dari kurangnya insiatif memanfaatkan potensi dari rumah untuk menambah penghasilan.

2. Kurangnya pelatihan dalam pemanfaatan pekarangan rumah yang dapat dimanfaatkan untuk bercocok tanam dalam memenuhi kebutuhan pangan dan pendapatan keluarga. Selama ini kegiatan pengabdian di kalangan akademisi maupun instansi terkait dalam memberikan pelatihan-pelatihan kepada masyarakat desa/gampong Baroh Langsa Lama belum optimal

3. Minimnya bekal keterampilan dan pengetahuan mitra dalam pemanfaatan pekarangan rumah. Dengan membekali mitra dengan keterampilan memanfaatkan pekarangan rumah, akan dapat mendatangkan menguntungkan selain memenuhi kebutuhan pangan keluarga juga mampu menambah pendapatan keluarga.

\section{Permasalahan yang Mendapat Prioritas yang Harus Diselesaikan}

Permasalahan mitra yang memerlukan prioritas adalah sebagai berikut:

1. Mengubah kebiasaan masyarakat yang kurang tanggap dengan cara menjalin kerjasama dengan instansi terkait dan tenaga penyuluh untuk membina dan memberdayakan mitra dengan memotivasi bahwa pemanfaatan pekarangan rumah untuk bercocok tanam merupakan modal serta peluang dalam meningkatkan ekonomi keluarga.

2. Akselerasi adopsi teknologi dengan cara membekali mitra dengan pengetahuan dan 
keterampilan sehingga nantinya mampu mandiri secara ekonomi

3. Adanya upaya mendirikan unit usaha dagang (UD) yang dikelola oleh masyarakat setempat. Dimana unit usaha dagang tersebut nantinya diharapkan dapat dijadikan sebagai tempat menampung bahan-bahan pangan dari Gampong tersebut.

\section{Tujuan Kegiatan}

Tujuan dari kegiatan ini adalah membina dan memberdayakan mitra dengan memotivasi bahwa pemanfaatan pekarangan rumah untuk bercocok tanam merupakan modal serta peluang dalam meningkatkan ekonomi keluarga

\section{METODE}

Pelatihan dilaksanakan di kantor Geuchik Baroh Langsa Lama pada tanggal 3 September 2020. Program ini diusul sebagai bentuk jawaban dari permasalahan berkurangnya penghasilan masyarakat terutama buruh harian lepas akibat masa pandemi yang mengharuskan stay at home dan melakukan social distancing agar tetap produktif dan menghasilkan uang dengan cara memanfaatkan pekarangan rumah dengan berbudidaya metode vertical garden yang dapat dikembangkan untuk meningkatkan ekonomi keluarga setempat dan sekaligus merubah perilaku usaha tani yang lebih efisien serta ramah lingkungan yang menuju ke pertanian berkelanjutan (sustainable agriculture).

Metode yang digunakan dalam kegiatan ini adalah metode penyuluhan dalam bentuk : (1) Pemaparan, diskusi dan tanya jawab, (2) Pelatihan dan demonstrasi langsung dengan melibatkan peserta secara aktif, (3) Aplikasi hasil kegiatan pelatihan atau demonstrasi yaitu membuat pot vertical garden dan melakukan budidaya dengan memanfaatkan paralon bekas yang tidak berguna, (4) Pemberian sarana dalam pengaplikasian pembuatan metode vertical garden. Penjabaran metode dapat dilihat pada tabel 1 di bawah ini.

Materi yang diberikan kepada para peserta dilakukan baik melalui penyuluhan maupun diskusi dan tanya jawab yang meliputi: Pengetahuan tentang budidaya metode vertical garden, pemanfaatan barang-barang bekas untuk budidaya tanaman, dan berbudidaya dengan lahan sempit. Lokasi pengabdian adalah di kantor geuchik Baroh Langsa Lama.

Tabel 1. Metode Pelaksanaan Kegiatan Pengabdian

\begin{tabular}{|c|c|c|c|c|}
\hline No & Pelaksanaan Kegiatan & Metode Pendekatan & Target & Partisipasi Mitra \\
\hline 1 & $\begin{array}{l}\text { Pengurusan perizinan ke } \\
\text { Kelurahan }\end{array}$ & Perizinan & $\begin{array}{l}\text { Surat Izin kelurahan } \\
\text { mengadakan } \\
\text { kegiatan }\end{array}$ & $\begin{array}{l}\text { Menyediakan tempat } \\
\text { dan akomodasi }\end{array}$ \\
\hline 2 & $\begin{array}{l}\text { Sosialisasi pentingnya } \\
\text { mengkonsumsi sayur } \\
\text { sehat }\end{array}$ & $\begin{array}{l}\text { Penyuluhan mengenai } \\
\text { pentingnya } \\
\text { mengkonsumsi } \\
\text { sayuran sehat agar } \\
\text { daya tahan tubuh } \\
\text { bagus. }\end{array}$ & $\begin{array}{l}\text { Pengetahuan akan } \\
\text { pentingnya } \\
\text { mengkonsumsi } \\
\text { sayuran sehat agar } \\
\text { daya tahan tubuh } \\
\text { bagus. }\end{array}$ & $\begin{array}{l}\text { Menyediakan tempat, } \\
\text { dan mengikuti } \\
\text { kegiatan praktek }\end{array}$ \\
\hline 3 & $\begin{array}{l}\text { Sosialisasi wawasan } \\
\text { tanaman hortikultura dan } \\
\text { manfaat ekonomis }\end{array}$ & $\begin{array}{l}\text { Penyuluhan mengenai } \\
\text { wawasan tanaman } \\
\text { sayuran hortikultura } \\
\text { dan extra income dari } \\
\text { metode vertical garden }\end{array}$ & $\begin{array}{l}\text { Pengetahuan akan } \\
\text { tanaman sayuran } \\
\text { hortikultura dan } \\
\text { manfaat ekonomis } \\
\text { dari metode vertical } \\
\text { garden }\end{array}$ & $\begin{array}{l}\text { Menyediakan tempat, } \\
\text { dan mengikuti } \\
\text { kegiatan praktek }\end{array}$ \\
\hline 4 & $\begin{array}{l}\text { Pelatihan } \\
\text { sayuran }\end{array}$ & $\begin{array}{l}\text { Praktek langsung } \\
\text { pelatihan penanaman } \\
\text { dengan metode vertical } \\
\text { garden }\end{array}$ & $\begin{array}{lr}\text { Sayuran } & \\
\text { hortikultura } & \text { sudah } \\
\text { ditanam } & \text { dengan } \\
\text { metode } & \text { vertical } \\
\text { garden } & \end{array}$ & $\begin{array}{l}\text { Menyediakan tempat, } \\
\text { dan mengikuti } \\
\text { kegiatan praktek }\end{array}$ \\
\hline 5 & Pelatihan pembibitan & $\begin{array}{l}\text { Praktek langsung } \\
\text { pembibitan benih di } \\
\text { media persemaian. }\end{array}$ & $\begin{array}{lr}\text { Bibit sudah } & \text { dapat } \\
\text { dipraktekkan } & \text { dan } \\
\text { disediakan } & \text { oleh } \\
\text { mitra } & \end{array}$ & $\begin{array}{l}\text { Menyediakan tempat, } \\
\text { dan mengikuti } \\
\text { kegiatan praktek }\end{array}$ \\
\hline
\end{tabular}

Melalui program ini, diharapkan para buruh harian lepas mendapatkan pengetahuan dan pemahaman yang jelas tentang pemanfaatan pekarangan rumah untuk memenuhi kebutuhan pangan dan pendapatan keluarga serta luaran yang diperoleh dari hasil pengabdian ini 
diharapkan menjadi bekal wawasan pengetahuan maupun keterampilan dan dapat meningkatkan perekonomian para buruh harian lepas agar tetap produktif dan menghasilkan uang pada masa pandemi serta akan merubah perilaku usaha tani yang lebih efisien dan ramah lingkungan sehingga menuju ke pertanian berkelanjutan (sustainable agriculture).

\section{HASIL DAN PEMBAHASAN}

Kegiatan Pelatihan dimulai dengan pemaparan bahwa saat ini Indonesia mengalami resesi karena adanya pandemi covid 19, yang artinya daya beli masyarakat menurun, sehingga mitra dihimbau untuk dapat memenuhi kebutuhan pangan, minimal sayur mayur secara mandiri. Dalam kegiatan presentasi, pembuka acara sekaligus moderator adalah Muhammad Rizqi Zati SPd, $\mathrm{MSi}$, kemudian presentasi pelatihan budidaya metode vertical garden dilaksanakan oleh Murdhiani STP,MP yang meliputi pelatihan pembuatan paralon sebagai media tanam sampai dengan pembibitan, dan pemaparan pengelolaan pemasaran hasil sayuran oleh Dhian Rosalina, SE, MM.

Tim melakukan penyuluhan pentingnya mengkonsumsi sayuran yang sehat karena konsumsi sayur juga terbukti efektif untuk mencegah berbagai penyakit berbahaya, termasuk penyakit Covid-19 yang saat ini mewabah. Sayur mengandung banyak vitamin dan mineral yang dibutuhkan oleh tubuh. Kandungan zat gizi yang ada pada sayuran memiliki peran, salah satunya sebagai antioksidan yang dapat menangkal radikal bebas. Radikal bebas sendiri merupakan salah satu penyebab terjadinya berbagai penyakit dan infeksi. Tak hanya itu, vitamin dan mineral juga membantu meningkatkan daya tahan tubuh. Daya tahan tubuh yang kuat sangat diperlukan untuk mencegah infeksi akibat virus corona. Selain mengandung vitamin dan mineral, sayur juga mengandung serat yang dapat menjaga kesehatan pencernaan, mencegah kegemukan, dan meningkatkan daya tahan tubuh. Saluran pencernaan adalah organ yang menghasilkan kekebalan tubuh. Dengan mengonsumsi serat yang cukup, saluran pencernaan dapat merangsang pertumbuhan bakteri-bakteri baik yang dapat menstimulasi sistem kekebalan tubuh.

Tim melakukan pengenalan tanaman hortikultura meliputi sayur sayuran yang memiliki masa panen dua sampai dengan tiga bulan, seperti bayam, kangkung, sawi, tomat, cabai, brokoli, gambas, pare, daun bawang, dan labu. Selain pengenalan jenis sayuran yang akan ditanam, tim akan memberikan wawasan mengenai pentingnya penganekaragaman tanaman sayuran yang dikonsumsi, agar daya tahan tubuh menjadi lebih baik untuk terhindar dari virus covid 19. Serta wawasan mengenai pertimbangan ekonomis karena masa pandemi covid 19 yang mengharuskan masyarakat melakukan social distancing dan stay at home. Masyarakat dapat memanfaatkan waktu luang dengan melakukan budidaya yang dapat memenuhi kebutuhan sayuran rumah tangga, serta apabila hasil panen melimpah dapat dijual yang mendatangkan extra income. Kegiatan ini dapat dilihat pada gambar 1 berikut ini:

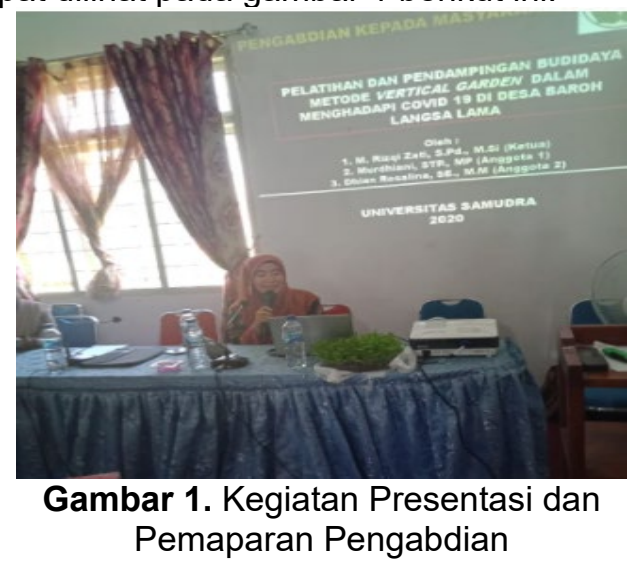

Dalam pelatihan ini, tim memaparkan bahwa pipa paralon dapat digunakan sebagai media tanam yang mudah dan praktis digunakan untuk menanam sayur sayuran. Dengan langkah langkah sebagai berikut 1) Pembuatan rak vertical garden dapat menggunakan bahan khusus seperti bambu, kayu, pipa paralon, pot gantung. Untuk pengabdian ini menggunakan paralon bekas menghemat penggunaan lahan tapi dapat meningkatkan produksi. 2) Pipa paralon yang ideal minimal berukuran 3" agar cukup untuk menampung media tanam. Semaikn besar ukuran pipa paralon, maka semakin baik untuk menanam. 3) Cara membuat tempat media menggunakan paralon bekas yaitu menentukan jarak antar lubang tanam dan ukuran sesuai keinginan. 4) Setelah itu potong bagian yang ingin dilubangi sebagai lubang tanam. 5) Panaskan bagian lubang tanam dengan api, setelah dipanaskan segera masukkan botol yang sesuai untuk membuat lubang tanam. 6) Setelah selesai melubangi, dudukan dibuat dengan menggunakan semen dan pasir (beton). 7) Agar pipa paralon dapat berdiri tegak dan mampu menopang tanaman. Jika tidak ada semen dan pasir, bisa juga menggunakan kayu. Setelah selesai isi pipa paralon tersebut dengan media tanam

Kemudian, mitra diperkenalkan dengan pengenalan media tanam, media tanam adalah tempat tumbuhnya tanaman untuk menunjang perakaran. Dari media tanam inilah tanaman menyerap makanan berupa unsur hara melalui 
akarnya. Media tanam yang akan digunakan yaitu campuran antara tanah, pupuk kompos, dan sekam dengan perbandingan 1:1:1. Setelah semua bahan terkumpul, dilakukan pencampuran hingga merata. Tanah dengan sifat koloidnya memiliki kemampuan untuk mengikat unsur hara, dan melalui air unsur hara dapat diserap oleh akar tanaman dengan prinsip pertukaran kation. Sekam berfungsi untuk menampung air di dalam tanah sedangkan kompos menjamin tersedianya unsur hara yang diperlukan tanaman. Campuran media tanam kemudian dimasukkan ke dalam paralon hingga penuh. Untuk memastikan tidak ada ruang kosong, dapat digunakan bambu kecil atau kayu untuk mendorong tanah hingga ke dasar wadah. Media tanam di dalam paralon diusahakan agar tidak terlalu padat supaya air mudah mengalir, juga supaya akar tanaman tidak kesulitan "bernafas" dan tidak terlalu renggang agar ada keleluasaan dalam mempertahankan air dan menjaga kelembaban.

Kemudian, mitra diperkenalkan dengan tahap persiapan bibit dan penanaman tanaman. Persiapan bibit sebaiknya dilakukan sebelum pembuatan pot, sehingga saat pembuatan rak sudah selesai bibit juga sudah siap untuk dipindahkan ke dalam pot vertical garden. Untuk penyemaian benih bisa menggunakan wadah khusus tray penyemaian benih atau bisa juga menggunakan gelas plastik bekas minuman. Wadah diisi media tanam seperlunya dan memiliki lubang di bagian bawah untuk mengeluarkan kelebihan air. Jumlah benih yang dapat disemaikan disesuaikan dengan ukuran wadahnya, dalam hal ini jarak tanam benih diatur sedemikian rupa agar tidak berdempetan. Semai benih dalam wadah yang sudah terisi dengan media tanam, lakukan penyiraman secara periodik sampai bibit siap pindah tanam. Benih akan berkecambah 2-3 minggu setelah semai. Bibit siap dipindahkan apabila sudah tumbuh 4-5 daun. Seperti apa media paralon dan benih sayur dapat dilihat pada gambar 2 .

Dari serangkaian kegiatan yang dilaksanakan, mitra cukup antusias mengikuti kegiatan, hal ini terlihat bahwa tidak ada peserta yang meninggalkan ruangan sebelum acara selesai. Kegiatan ini diakhiri dengan sesi Tanya jawab. Pertanyaan mitra cukup bervariasi, dimulai dari penggunaan media lain seperti bambu, botol bekas, dan lain sebagainya untuk media tanam, kemudian pertanyaan berikutnya adalah bagaimana komposisi tanah dan pupuk yang tepat untuk pembibitan, sampai dengan pertanyaan mengenai komersialisasi hasil sayur mayur. Pertanyaan pertanyaan yang muncul segera direspon oleh tim, dan tim pun melakukan reka ulang pelatihan sampai mitra memahami teknik budidaya vertical garden dengan baik.

Setelah kegiatan diskusi dan Tanya jawab usai, mitra diminta melakukan praktek dirumah masing masing, dimana tim pengabdian secara berkala melakukan monitoring ke rumah mitra yang ditunjuk untuk mengevaluasi keberhasilan program pengabdian. Dimana terdapat lima orang peserta yang bersedia untuk dievaluasi secara berkala.

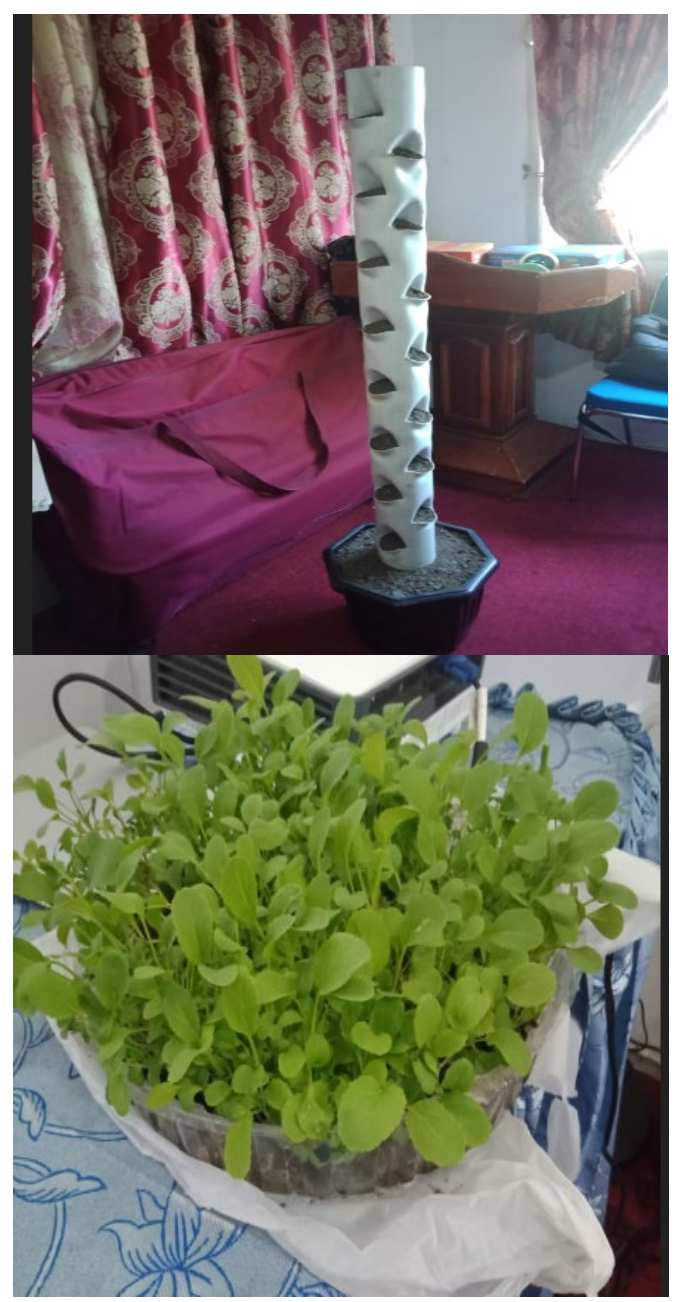

Gambar 2. Paralon Sebagai Media Tanam dan bibit sayuran

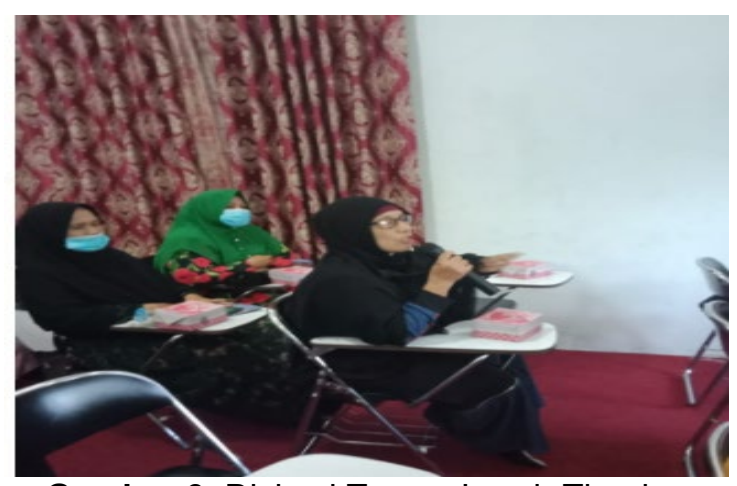

Gambar 3. Diskusi Tanya Jawab Tim dan Mitra 


\section{SIMPULAN DAN SARAN \\ Simpulan}

Kesimpulan dari kegiatan ini adalah sebagai berikut : Pertama, kegiatan berjalan dengan baik, mitra mendapatkan pengetahuan dan ilmu baru dalam memanfaatkan media seperti paralon bekas, maupun alat lainnya dapat digunakan menjadi media tanam, tanpa memerlukan tanah pekarangan yang luas. Kedua, Adanya motivasi tersendiri bagi mitra untuk dapat menekuni budidaya dengan metode vertical garden, yang apabila dikelola dengan baik, selain mampu memenuhi kebutuhan sayur mayur juga dapat menghasilkan extra income bagi keluarga, yang saat ini diperlukan dalam menghadapi pandemi covid 19. Ketiga, Kepastian kegiatan pengabdian berjalan dengan efektif adalah kesanggupan mitra mempraktikkan pelatihan dan bersedia di evaluasi secara berkala oleh tim pengabdian.

\section{Saran}

Saran dari pelaksanaan kegiatan ini adalah, pertama perlu adanya pelatihan intensif untuk meningkatkan kemandirian mitra dalam mendapatkan penghasilan ekstra di tengah pandemik. Kemudian yang kedua, pelatihan pelatihan kepada mitra sebaiknya tetap mengutamakan kondisi ekonomi yang merupakan buruh harian lepas, dimana pelatihan tersebut dapat memanfaatkan benda benda disekitar tempat tinggal yang mudah dan murah didapatkan.

\section{DAFTAR RUJUKAN}

Damayanti Asikin, Rinawati, T. M. (2016). Vertical Garden Dan Hidroponik Sebagai Elemen Arsitektural Di Dalam Dan Di Luar Ruangan. Jurnal Ruas.

Hadiwardoyo, W., Tinggi, S., Ekonomi, I., \& Barat, J. (2020). KERUGIAN EKONOMI NASIONAL AKIBAT PANDEMI COVID-19. Journal of Business and Entrepreneurship, Volume 2 N(April), 83-92.

Hanoatubu, S. (2020). Dampak Covid 19 Terhadap Perekonomian Indonesia. EduPsyCouns Journal, 2, 146-153.

Karim, A. (2020). Peningkatan Ekonomi Pedesaan dalam Menunjang Pergerakan Pertumbuhan Ekonomi Perkotaan di Masa Pandemic Global.

Masniadi, R., Angkasa, M. A. Z., Karmeli, E., \& Esabella, S. (2020). Telaah Kritis Ketahanan Pangan Kabupaten Sumbawa dalam Menghadapi Pandemi Covid-19. Sosial Sciences and Humanities, 1(2), 109-120.
Yudhi Harini Bertham*) , Abimanyu Dipo Nusantara dan Bambang Gonggo. (2020). Penguatan Ketahanan Pangan dalam Rangka Menghadapi Potensi Krisis Akibat Pandemi Covid-19 melalui Budidaya Hortikultura Berbasis Organik Hayati di Lahan Pekarangan di Kelurahan Beringin Raya Kota Bengkulu Jurnal Pengabdian Masyarakat Dewantara. 3(2), 14-18.

Putri, E., Syafril, E., Hutama, A., Nugraha, A., \& Semarang, U. N. (2020). Proceeding International Webinar Malay Local Wisdom in the Period and After the Plague.

Saragih, B., \& Mulawarman. (2020). Gambaran Kebiasaan Makan Masyarakat Pada Masa Pandemi Covid-19. Research Gate, 19(April), 1-12. 